Andreász Kosztopulosz - Éva Kuruczleki (eds.) (2020): The Challenges of Analyzing Social and Economic Processes in the 21st Century. University of Szeged Faculty of Economics and Business Administration, Szeged, https://doi.org/10.14232/casep21c.4

\title{
The possibilities of electric vehicles nowadays
}

\author{
Áron Drabancz
}

\begin{abstract}
Global warming is one of the biggest problems in the world: international organizations, states, companies and individuals must respond to the challenges that arise. This fact has led to significant changes in the automotive industry, which can revolutionize the way the industry operates in the future. The aim of my study is to examine how the strengthening of sustainability aspects influenced the transformation of the automotive industry, with special regard to the spread of electric cars. I also examined how markets responded to technological change, thus the announcements that help drive the spread of electric cars have had a positive impact on the value of companies in recent years. With the help of event analysis, I have shown that equities had systematically outperformed after innovative announcements, but the effect was not always significant.
\end{abstract}

Keywords: electric vehicle, event analysis, innovation

„Failure is only the opportunity more intelligently to begin again."

Henry Ford

\section{Introduction}

The development of the automotive industry began during the Second Industrial Revolution (1871-1914). The appearance of the engine and the mechanical improvements made it possible to replace the horse-drawn vehicles. In the early stages of the automotive industry, electric cars were dominant compared to steam and gasoline cars, as they started faster and were easier to handle (Bobák 2013). This is well illustrated by the fact that electric vehicles accounted for $38 \%$ of traffic in the United States at the end of the 19th century. However, at the beginning of the 20th century there were significant changes in the production of gasoline vehicles: In 1912, Charles Kettering invented the electric starter motor, which made it easier to start gasoline vehicles, and then the Henry Ford's conveyor belt made the production of gasoline cars considerably cheaper and faster. As a result of technological advancements, Ford Model T has become the most popular car brand. Electric cars have been pushed out of the car market due to their high cost and short range, and for almost 100 years, cars powered by internal combustion engines have only been truly competitive in the market. By the end of the 20th century, however, the issue of global climate change was becoming more prominent, calling into question the continued legitimacy of petrol vehicles. There is a growing social demand for more environmentally friendly car production: hybrid, electric or hydrogen powered vehicles have been appearing on the market. In many countries, environmental movements have been organized to bring about radical changes in reducing car emissions. As a result, developed countries have begun to reduce environmental 
damage by facilitating the proliferation of electric cars through incentives (e.g. tax burden relief, bus lane use) and legislation (e.g. mandatory reduction of average $\mathrm{CO} 2$ emissions from car fleets).

According to Bullard (2019), the initiatives have largely been successful, as by 2022 the price of electric cars may be below the cost of petrol or diesel powered vehicles. The pace of technological change is shown by the variable estimation of crossover point - when electric vehicles become cheaper than their combustionengine equivalents - which was 2026 in 2017 and 2024 in 2018. Thus, a new "renaissance" of electric cars may begin in the near future.

In my paper, I will use the event analysis methodology to examine how the market has judged electromobility and how it has rewarded innovative announcements by individual firms. In my hypothesis, companies that have been more intensively involved in the development of cars with renewable energy sources have outperformed the market. In other words, investors in the automotive industry have supported companies that have been at the forefront of developing electric motor vehicles.

In the next chapter of my paper, I present the most important alternative propulsion technologies and the current major limitations of electric motoring. Then, in Chapter 3, I will conduct an event analysis among the largest automotive companies and show that the companies that laid the foundation for the new industry structure performed better or worse than the market. In the final section of the paper, I deal with the evaluation of the results and describe the most important conclusions.

\section{Green mobility}

In addition to improving the efficiency of conventional engines, automotive manufacturers are basically developing either electric or hydrogen powered cars. The hybrid vehicles are also important, which have both conventional and electric motors, and significant market shares. This technical solution combines the benefits of petrol and electric cars.

A hybrid car that can be powered by both electric power and an internal combustion engine is considered to be a mixture of an electric car and a gasoline powered vehicle. The electric motor is really efficient at low speeds, the internal combustion engine at higher speeds. Thus, in slow city traffic or traffic jams, the lowerpowered electric drive is used, while on the highway the internal combustion engine runs. In some hybrid cars, the electric motor provides only the extra power needed for acceleration, and the car cannot be driven by a pure electric motor. The hybrid car thus combines the benefits of electric and gasoline drive. This may be the reason for its relatively high penetration: since $2007,2 \%$ of cars sold in the United States have been linked to hybrid technology (Voelcker 2017). However, in most of the cars sold, the electric motor only serves as an auxiliary function to the internal combustion engine, hybrids with more powerful electric motors (plug-in hybrids) accounting for only $0.42 \%$ of US car sales (own calculation based on IEA (2017) data). Hybrid cars could become very popular in the future if the electric car catches up with competitiveness but does not outperform conventional cars. Thus, the synergy resulting from the combination of two different technologies could make the hybrid car the most widespread vehicle. 
The hydrogen car is the least common of the "green" cars. This is due to the immaturity of the technology and the high cost of production. The operation of the hydrogen car is based on the reversing of electrolysis: in the fuel cell, hydrogen combines with oxygen and generated electricity drives the car. One of the challenges facing hydrogen cars is that explosions are serious problem, as fuel cells have to deal with one of the most dangerous, most flammable materials, hydrogen. Nowadays, it is still very expensive for car manufacturers to ensure that hydrogen in fuel cells does not explode under any circumstances. That's why this technology first appeared on buses, since the cost and consumption of the bus can give a relatively fast return on the investment. Hydrogen propulsion is therefore particularly effective for large vehicles that need to travel long distances every day (CAFCP 2012).

The technology has continued to evolve in recent years, with only $0.5 \mathrm{~kW}$ of energy being released per cubic decimeter in 1999, compared with $2.5 \mathrm{~kW}$ in 2012 . In addition, the latest fuel cells can operate in colder environments. Previously they were not safe below $0^{\circ} \mathrm{C}$ and today they are even operating at $-30^{\circ} \mathrm{C}$ (Greene 2013, p. 6-7). However, many companies believe that the technology is unlikely to be competitive by 2025 , and significant cost reductions are unlikely until then (Greene 2013, p. 17, HydrogenEurope 2018, p. 40). The immature nature of the technology is well illustrated by the fact that there were only 376 hydrogen refuelling stations in the world in 2018, compared to more than 500,000 electric charging stations, of which more than 140,000 were fast chargers (IEA 2019a, IEA 2019b). However, in the long run, hydrogen cars can become a viable alternative. The main reason is that their charging time is short, only 5 minutes. On the other hand, with a quick charger, it takes at least 25-45 minutes to charge an electric car. As a result, $78 \%$ of senior executives in the automotive industry believe that hydrogen cars can be a real alternative to petrol and diesel powered vehicles (KPMG 2017, p. 14).

Battery-powered electric cars are well-known to consumers, especially through Tesla's activities. These vehicles are particularly popular in Norway, thanks to particular generous discounts: in 2017, 39\% of cars sold were pure electric (Knudsen-Doyle 2018). Such cars have a relatively high worldwide penetration rate, in 2016, $0.68 \%$ of car sales were attributable to electric cars (own calculation based on IEA 2017 data). In 2010 it was only around 0.01\%, but between 2010 and 2016, electric car sales increased by an average of $104 \%$ per year. If the trend continues, assuming a 5\% annual increase in car sales, electric cars could become the market leader within 10 to 15 years. However, the widespread adoption of new technology today is set back by three factors (PwC 2014, p. 14):

1. Relatively low number of charging stations and length of charging time.

2. Short range of cars $(150-200 \mathrm{~km})$.

3. The high price of cars.

In the following chapters, I will explain in detail the factors influencing the radical diffusion of new technology, and examine how car manufacturers have helped break down barriers and contributed to the transformation of the automotive industry. 


\subsection{Charging stations}

Increasing the number of charging stations is a key factor in increasing the penetration of electric cars (IEA 2019b). The vast majority of motorists are only willing to replace their internal combustion car if their mobility is not reduced when using an electric car. In recent years, fast and slow charging network coverage has increased tremendously (Table 1), exceeding the growth rate of electric car sales (IEA 2019b, p. 218).

Slow chargers can charge a significant amount of discharged batteries in about 8-10 hours, while for fast chargers it is 25 to 45 minutes. Slow chargers are therefore most often used in the car owner's home. The owner puts his own slow charger on his car every night so he can start working the next day with fully charged batteries.

Table 1 The number of publicly accessible slow and fast chargers in the United States and World

\begin{tabular}{ccccc}
\hline & \multicolumn{2}{c}{ World } & \multicolumn{2}{c}{ United States of America } \\
& Fast chargers & Slow chargers & Fast chargers & Slow chargers \\
\hline 2009 & 47 & 373 & 47 & 373 \\
2010 & 372 & 3682 & 60 & 482 \\
2011 & 1356 & 11311 & 489 & 3903 \\
2012 & 3332 & 29620 & 1464 & 11695 \\
2013 & 5044 & 43932 & 1877 & 14990 \\
2014 & 16762 & 90859 & 2518 & 20115 \\
2015 & 26784 & 156072 & 3524 & 28150 \\
2016 & 73851 & 257518 & 3079 & 35089 \\
2017 & 107650 & 325598 & 3436 & 39601 \\
2018 & 143502 & 395107 & 4242 & 50258 \\
\hline
\end{tabular}

Source: own construction based on IEA (2019b) data

The fast charging network has been set up that the car owner can reach more distant destinations, so its coverage can be a decisive factor for electric cars. If the coverage of the fast charging network in the United States were even, these chargers would be approximately 48 kilometers apart today (own calculation based on IEA 2019b). However, fast chargers of the automakers are not always compatible, so presumably the country coverage is still incomplete. However, given the population density and distribution of the federal states, it can be stated that in major cities and on the motorways connecting larger cities, the charging network is now close to dense not to cause inconvenience to consumers. Tesla's Supercharger network have well built in the United States, Western Europe, Eastern China and Japan. The filling network makes it possible to reach any of the major cities in Western Europe today, so you can easily go from Narvik to Calabria or Lisbon to Budapest by Tesla car (Supercharge.info 2020). The expansion of the charging network in the future will make it possible to reach smaller towns and then rural settlements safely. The main obstacle to the spread of electric cars lies in the slow charge time. Unlike petrol and diesel vehicles few minutes of charging time, it takes at least half an hour to charge electric vehicles on the high-speed network. However, the new ultra-fast chargers could charge car batteries in 15 minutes (REW 2019). With this development, one of the biggest obstacles to the proliferation of electric cars would be overcome. 


\subsection{Range}

The shorter range of electric cars is still a deterrent for consumers. Industry analysts say there is a "range anxiety" phenomenon, which puts a strong constraint on consumers purchasing a vehicle if they think that the range of the vehicle is not sufficient for daily use. According to international experts, the minimum distance that can be covered by pure electric vehicles is at least 200-300 kilometers in order to grow the electric market substantially ( $\mathrm{PwC} 2014$, p. 15). A study by FigenbaumKolbenstvedt (2016) confirms this, because $40 \%$ of Norwegian electric car owners saying that cars need a range of at least 200 kilometers to get more people interested in electric motoring. However, only more than $20 \%$ of traditional car owners believe that such a range is sufficient. At over 300 kilometers, there is a majority in both groups who believe electric cars would be competitive for society. At a distance of 500 kilometers, the ratio was close to $100 \%$ for electric car users and almost $90 \%$ for traditional car owners (Figenbaum-Kolbenstvedt 2016, p. 77).

Predictions indicate that a $300 \mathrm{~km}$ range will be available in most models in the near future. A good example of the increase in range is the Nissan Leaf: the model launched in 2011 and later it was upgraded and the range of the 2016 Nissan Leaf was nearly 50\% bigger than the original version (Figenbaum-Kolbenstvedt 2016, p. 62). Norwegian electric car users estimate that today's models can travel up to 100-150 kilometers on a single charge. The owners of the Tesla Model S have stated that their car has already crossed this psychological limit and is able to cover at least 300 kilometers on a single charge (Figenbaum-Kolbenstvedt 2016, p. 61).

However, practical examples show that the range of 200-300 kilometers is just a psychological limit, and in most cases consumers do not take advantage of their car. The Norwegian survey looked at the car usage patterns of owners of electric cars and conventional cars. They found that conventional car users drove an average day of 50 kilometers and electric car users drove an average day of 66 kilometers, so average distance did not reduce by the use of an electric car. These values are well below the 200 kilometers, with less than $5 \%$ of car owners using their car for distances greater than 200 kilometers (Figenbaum-Kolbenstvedt 2016, p. 44). Although the rarer longer roads are still clearly a problem for electric car owners, the range of today's models in urban transport is satisfactory. The range of future models, together with the development of the fast charging network, can help to bridge the mobility gap between conventional and electric cars.

\subsection{Pricing}

The last barrier to the proliferation of electric cars is that they are still relatively expensive for middle class. New technology products are usually available at relatively high prices and low added value at the start of their life cycle. Some customers choose a new product based on their individual, specific preferences, which is too expensive and low value for the rational consumer:

1. high price - low value

2. medium price - average value

3. low price - high value 
The electric car has been in the 1. segment for a long time because of the high price of the product, coupled with the lack of charging stations and short range, which has limited customer mobility compared to users of conventional cars. However, environmentally conscious buyers and state tax breaks have helped to develop technology, which has lowered prices and led to new customers. As a result of increasing economies of scale and technological advances, the price of batteries, the main cost factor for electric cars, has declined significantly in recent years. Cost reductions have surpassed industry expectations: Analysis expected lithium-ion batteries would cost $\$ 200$ per kilowatt-hour by 2020 and $\$ 160$ per kilowatt-hour by 2025 (McKinsey 2012). However, the average price of lithium-ion batteries in 2017 has barely exceeded $\$ 200$ per kilowatt hour, and, in 2019 , it was under $\$ 160$ per kilowatt hour (Figure 1, Holland 2019). As a result of the cost reductions, mediumsized electric cars have also appeared, which can further expand the number of consumers. In America, in 2015, the average selling price of new cars was $\$ 34,500$ with tax breaks, however, you can buy nearly a dozen electric cars at this price nowadays. The GM Bolt or Tesla Model 3 electric car, is already approaching the "people's car" category in the United States, starting at less than $\$ 30,000$, with a range of almost 400 kilometers on a single charge (Szandányi 2016, Portfolio 2017). Thus, the higher price associated with electric cars will gradually disappear, and in the future electric cars may become real competitors of conventional cars.

Figure 1 The price of lithium-ion batteries in kilowatt hour from 2010 to 2019

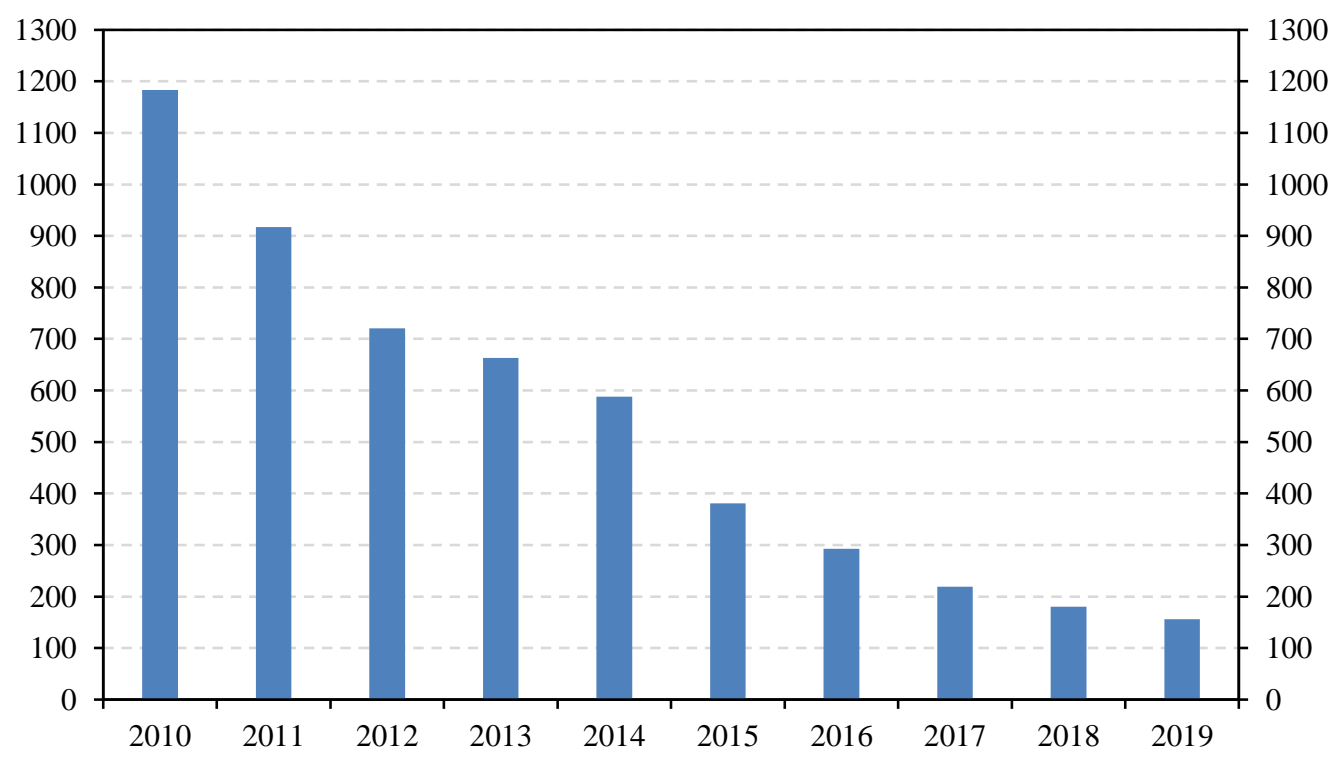

Source: Holland (2019) based on Bloomberg NEF data 


\section{Event analysis}

In this section, I examine the impact of announcements on electric cars on the stock market. I analyze the performance of Toyota, General Motors, Ford and Tesla between November 19, 2011 and January 31, 2018. ${ }^{1}$ My aim is to demonstrate through the event analysis methodology that innovative initiatives have been market-favored, resulting in positive abnormal returns on the shares of reporting companies.

I chose General Motors, Ford and Toyota because they are significant players, their share of production is $25.8 \%$ (own calculation based on OICA 2016). Toyota produced the most cars in 2016, GM the fourth and Ford the fifth (OICA 2016). Tesla's market share is so far negligible, but it has a unique ability and reputation for innovation in the electric motor industry, and its market capitalization is significant. Furthermore, shares of all four automakers are traded on NASDAQ or the New York Stock Exchange, which have the same trading hours. ${ }^{2}$ As a result, the price data of the four companies is consistent over time, and external news is always integrated into the price of their shares at the same time. This allows us to measure unique effects with the help of event analysis. In this section, I examine the innovative, electric car related announcements of the four automotive manufacturers. The exception is the announcement of the Volkswagen scandal, which is not closely related to any company, but has had a significant impact on the industry.

The essence of event analysis is that asset prices contain all public information, so new relevant news must have an immediate price effect (Campbell et al. 1997). The model states that the return of a share is based on the market return (Fama et al. 1969):

$$
R_{i, t}^{*}=\alpha_{i}+\beta_{i} R_{m, t}
$$

where $\alpha_{i}$ and $\beta_{i}$ are estimated parameters from the regression, $R_{m, t}$ is the market return, $R_{i, t}^{*}$ is the estimated return on the share. The difference between the estimated return of a share $\left(R_{i, t}^{*}\right)$ and the actual realized return $\left(R_{i, t}\right)$ is called an abnormal return:

$$
\varepsilon_{i, t}=R_{i, t}-R_{i, t}^{*}
$$

In most cases, the value of abnormal returns is not zero, as there are many factors that influence the share price. The significance of these can be examined in the framework of the APT model, characteristic factors could be (Ross 1976):

1. Industry effects: state regulation; changes in consumer preferences; appearance of new competitors, etc.

2. Company Announcements: change in profitability; change of strategic direction; acquisitions, etc.

3. Trading processes: buying or selling shares of large investors; closing positions; market microstructure, etc.

\footnotetext{
${ }^{1}$ As of November 19, 2011, share prices for all four car manufacturers are available. Download date: 02.02.2018.

2 The second (Volkswagen) and third (Hyundai) most car makers company did not have data on US trading values at Yahoo Finance (2018), so I could not include them in my analysis.
} 
Estimating the market and share price characteristics from past data and incorporating it into the model's analytical framework (see model in detail in Appendix) determines whether the event had a significant effect on the share price, significant abnormal returns were appeared or not. ${ }^{3}$ Therefore, the presence of a significant abnormal return indicates that the value of the company was significantly affected by the event. According to my hypothesis, in the case of a positive announcement concerning electric cars, I expect a positive abnormal return.

During the analysis, I used the S\&P500 index, which consists of the largest companies on the NASDAQ and the New York Stock Exchange, so it provide a good overview of market trends. I always calibrated the parameters of the model based on the daily return data of one year (252 trading day) preceding the event (Yahoo Finance 2018). The length of the event window is always 6 days, so I compared the estimated returns of nearly a week after the event with the actual realized returns. I accumulated the abnormal yields for each day and examined whether the abnormal yields were significantly different from zero.

\subsection{Volkswagen scandal}

In this section, I examine the impact of the Volkswagen scandal that erupted in the morning of September 18, 2015 on Tesla's and on the other three car makers' share prices. I wonder if the news resulted in a significant abnormal return.

Manufacturer of petrol and diesel powered vehicles have been hit hardest by the news, since the scandal has put the automotive companies' emissions reduction requirements on target. Then, numerous investigations were launched to assess whether other car manufacturers had manipulated their consumption data. As a result of the scandal, consumer demand for alternative fuel cars has increased. So, according to my hypothesis, Tesla had a positive abnormal return while the other three car makers had a negative abnormal return.

Calculation results for the scandal are shown in Table 2. Results are not significant at either $1 \%$ or $5 \%$, although it can be stated that after the outbreak of the scandal, Tesla reached positive cumulative abnormal returns at each time point, while the other three car makers showed negative cumulative abnormal returns, so after the scandal, Tesla outperformed its competitors.

The lack of significance may be due to the longer-lasting nature of the Volkswagen scandal. When the case came out, on September 18, 2015, it was only known that Volkswagen had cheated in measuring car emissions, so it had to withdraw 482,000 cars from its customers. It was later discovered that up to 11 million cars could be affected, most of which had to be recalled later. Furthermore, it was only at the end of the autumn when emissions investigations for the entire automotive industry began (Kollewe 2015).

\footnotetext{
${ }^{3}$ An abnormal return with a p-value of less than $1 \%$ is considered significant.
} 
Table 2 Cumulative Abnormal Returns (CARs) for Tesla and the three major automakers, and the associated p-values during the Volkswagen scandal

\begin{tabular}{lrrrrrrrr}
\hline & \multicolumn{2}{c}{ Tesla } & \multicolumn{2}{c}{ Toyota } & \multicolumn{2}{c}{ Ford } & \multicolumn{2}{c}{ GM } \\
& CAR & p-érték & CAR & p-érték & CAR & p-érték & CAR & p-érték \\
\hline 09.18 .2015 & $1,58 \%$ & $23,01 \%$ & $-0,57 \%$ & $31,99 \%$ & $-0,53 \%$ & $31,95 \%$ & $-0,86 \%$ & $24,83 \%$ \\
09.21 .2015 & $2,31 \%$ & $22,15 \%$ & $-0,64 \%$ & $35,55 \%$ & $-0,69 \%$ & $33,31 \%$ & $-0,97 \%$ & $29,26 \%$ \\
09.22 .2015 & $2,70 \%$ & $23,36 \%$ & $-1,63 \%$ & $22,10 \%$ & $-2,21 \%$ & $13,00 \%$ & $-1,60 \%$ & $23,21 \%$ \\
09.23 .2015 & $2,99 \%$ & $24,30 \%$ & $-1,86 \%$ & $22,41 \%$ & $-3,70 \%$ & $5,15 \%$ & $-2,41 \%$ & $17,00 \%$ \\
09.24 .2015 & $4,20 \%$ & $19,13 \%$ & $-1,53 \%$ & $28,87 \%$ & $-3,55 \%$ & $8,09 \%$ & $-3,00 \%$ & $14,50 \%$ \\
09.25 .2015 & $1,87 \%$ & $36,12 \%$ & $-0,03 \%$ & $49,62 \%$ & $-4,36 \%$ & $5,89 \%$ & $-3,04 \%$ & $16,35 \%$ \\
\hline
\end{tabular}

Source: own calculations based on Yahoo Finance (2018)

\subsection{Company announcements}

The three major automobile manufacturers and Tesla with numerous announcements have reinforced the notion that a radical change in the automotive industry could take place in the near future. After the Volkswagen scandal, this commitment was further strengthened. GM and Ford announced on October 2, 2017 that they will launch about 20 new electric vehicles by 2023 (Walz 2017). Toyota announced on December 18, 2017 that it will launch 10 hybrid cars in the early 2020s and intend to produce electric or hybrid vehicles throughout the supply chain by 2025. Its target is to sell 5.5 million electric vehicles in 2030, which $53.4 \%$ of its current production (own calculation based on OICA 2016, Lambert 2017).

Table 3 Cumulative Abnormal Returns (CAR) for Tesla and Toyota, Ford, and GM, and related p-values after demonstrating Ford and GM's electrical strategy

\begin{tabular}{rrrrrrrrr}
\hline & \multicolumn{2}{c}{ Tesla } & \multicolumn{2}{c}{ Toyota } & \multicolumn{2}{c}{ Ford } & \multicolumn{2}{c}{ GM } \\
& CAR & p-érték & CAR & p-érték & CAR & p-érték & CAR & p-érték \\
\hline 10.02 .2017 & $-0,53 \%$ & $40,19 \%$ & $-0,58 \%$ & $22,91 \%$ & $0,56 \%$ & $30,18 \%$ & $3,86 \%$ & $0,19 \%$ \\
10.03 .2017 & $0,97 \%$ & $37,36 \%$ & $-0,07 \%$ & $47,46 \%$ & $2,40 \%$ & $5,81 \%$ & $6,63 \%$ & $0,02 \%$ \\
10.04 .2017 & $2,63 \%$ & $23,88 \%$ & $0,98 \%$ & $23,65 \%$ & $1,97 \%$ & $14,63 \%$ & $7,19 \%$ & $0,10 \%$ \\
10.05 .2017 & $1,84 \%$ & $33,44 \%$ & $0,71 \%$ & $32,67 \%$ & $0,90 \%$ & $33,98 \%$ & $6,60 \%$ & $0,68 \%$ \\
10.06 .2017 & $2,26 \%$ & $31,90 \%$ & $1,47 \%$ & $20,31 \%$ & $1,58 \%$ & $25,82 \%$ & $9,15 \%$ & $0,11 \%$ \\
10.09 .2017 & $-1,56 \%$ & $38,34 \%$ & $1,70 \%$ & $19,14 \%$ & $2,10 \%$ & $21,50 \%$ & $10,22 \%$ & $0,10 \%$ \\
\hline
\end{tabular}

Source: own calculations based on Yahoo Finance (2018) 
Table 4 Cumulative Abnormal Returns (CARs) for Tesla and Toyota, Ford and GM, and related p-values after demonstrating Toyota's electrical strategy

\begin{tabular}{rrrrrrrrr}
\hline & \multicolumn{2}{c}{ Tesla } & \multicolumn{2}{c}{ Toyota } & \multicolumn{2}{c}{ Ford } & \multicolumn{2}{c}{ GM } \\
& CAR & p-érték & CAR & p-érték & CAR & p-érték & CAR & p-érték \\
\hline 12.18 .2017 & $-2,20 \%$ & $15,55 \%$ & $1,93 \%$ & $0,30 \%$ & $0,03 \%$ & $48,81 \%$ & $2,27 \%$ & $3,14 \%$ \\
12.19 .2017 & $-4,22 \%$ & $8,48 \%$ & $2,58 \%$ & $0,48 \%$ & $0,72 \%$ & $30,79 \%$ & $3,49 \%$ & $2,13 \%$ \\
12.20 .2017 & $-4,90 \%$ & $9,66 \%$ & $3,01 \%$ & $0,68 \%$ & $1,11 \%$ & $26,36 \%$ & $3,68 \%$ & $4,07 \%$ \\
12.21 .2017 & $-4,51 \%$ & $15,05 \%$ & $3,14 \%$ & $1,30 \%$ & $0,22 \%$ & $45,76 \%$ & $2,59 \%$ & $14,37 \%$ \\
12.22 .2017 & $-6,55 \%$ & $9,00 \%$ & $3,08 \%$ & $2,55 \%$ & $-0,07 \%$ & $48,83 \%$ & $2,33 \%$ & $19,65 \%$ \\
12.26 .2017 & $-9,00 \%$ & $4,69 \%$ & $3,04 \%$ & $3,93 \%$ & $0,28 \%$ & $45,59 \%$ & $1,59 \%$ & $25,71 \%$ \\
\hline
\end{tabular}

Source: own calculations based on Yahoo Finance (2018)

As a result of the "green" announcements, there is a positive abnormal return on car manufacturers' returns (Table 3 and Table 4). In the case of GM, the cumulative abnormal returns reported from October 2 till the end of the event window were also significant in every day. However, the results cannot be clearly interpreted, as GM also outlined the advanced development of self-driving vehicles, which may have had an impact on asset prices (Walz 2017). In the case of Ford, the plans outlined seemed more conservative - they did not increase the funding for developing electric cars, no information was provided on the planned number of electric cars - which may explain the company's lack of significant abnormal returns. As a result of Toyota's announcement, the company achieved positive abnormal returns throughout the next six days, which proved to be significant in the first three days.

Examining corporate announcements, it is not clear that electric and alternative propulsion developments have a positive impact on share prices. Although the above examples showed positive abnormal returns, in most cases, they were not significant. Then, I examined the significance of the estimated abnormal yield for each trading day. In connection with this, it can be basically stated that the clear presence of significant abnormal returns is mostly related to traditional announcements (e.g. change in profitability, change in dividend policy).

Thus, my hypothesis could not be proved. The direction of the abnormal yield associated with innovative announcements is the same as I have assumed, but it is usually not significant. This may indicate that the market rewards initiatives to transform the automotive industry, however, the speed of the transformation of the automotive industry and its precise picture are not yet clear to investors.

\section{Conclusion}

In this study, I examined the transformation of the automotive industry, with special regard to the potential of electric driving. In Chapter 2 of the study, I showed the new technologies and analyzed in detail the main limitations associated with electric motoring. In Chapter 3, I investigated the Volkswagen scandal and innovative electric car announcements on the stock market with the help of event analysis methodology. 
The hypothesis of my research could not be clearly proved. However, the analysis showed that at the event of Volkswagen scandal and other innovative announcements, the manufacturers which committed themselves developing alternative technologies outperforming the market. Although, in most cases, the cumulative abnormal returns were not significant, and recent years' significant abnormal returns were mainly attributable to traditional reporting. Overall, it is not clear that the market already favors companies actively developing this technology. In addition, one of the limitations of the research is that the electromobility are a quick changing emerging technology, so since the analysis of the 2018 stock market data, market events have been able to shape market conditions even further. Due to the complex transformation of the automotive industry, the future role of electric cars may not be fully defined today, but technology is likely to play an increasingly important role in our everyday lives.

\section{References}

Bullard, N. (2019): Electric car price tag shrinks along with battery cost. https://www.bloomberg.com/opinion/articles/2019-04-12/electric-vehiclebattery-shrinks-and-so-does-the-total-cost Accessed: January 14, 2020.

Bobák, Á. (2013): Száz éve buktak el a villanyautók - Elektromos autók a századfordulón. http://player.hu/tech-auto/auto-motor/villanyautok-a-szazadfordulon/ Accessed: July 02, 2017.

Campbell, J. Y. - Lo, A.W. - Mackinley, A. C. (1997): The Econometrics of Financial Markets. Princeton University Press, Princeton.

CAFCP (2012): A California Road Map: The Commercialization of Hydrogen Fuel Cell Vehicles. https://cafcp.org/sites/default/files/A California Road Map June 2012 (CaFCP technical version).pdf Accessed: January 14, 2020.

Holland, M. (2019): Powering The EV Revolution-Battery Packs Now At \$156/kWh, 13\% Lower Than 2018, Finds BNEF.

https://cleantechnica.com/2019/12/04/powering-the-ev-revolution-battery-packsnow-at-156-kwh-13-lower-than-2018-finds-bnef/ Accessed: January 15, 2020.

Lambert, F. (2017): Toyota announces major expansion of its electric car plans: 10 new BEVs, all models to have electric motors.

https://electrek.co/2017/12/18/toyota-electric-car-plans/ Accessed: February 01, 2018.

Fama, E. F. - Fisher, L. - Jensen, M. - Roll, R. (1969): The adjustment of stock prices to new information. International Economic Review, 10, 1-21.

Figenbaum, E. - Kolbenstvedt, M. (2016): Learning from Norwegian Battery-electric and Plugin Hybrid Vehicle Users. Institute of Transport Economics, Norwegian Centre for Transport Research, Oslo. www.toi.no/getfile.php?mmfileid=43161. Accessed: February 03, 2018.

Walz, E. (2017): GM Outlines Path to EVs and Zero Emissions, Bollinger Motors Surpasses 10,000 Reservations for its Electric Truck. http://www.futurecar.com/article-1495-1.html Accessed: February 01, 2018.

Greene, D. L. (2013): Status and Prospects of the Global Automotive Fuel Cell Industry and Plans for Deployment of Fuel Cell Vehicles and Hydrogen Refueling 
Infrastructure.

https://www1.eere.energy.gov/hydrogenandfuelcells/pdfs/fcev status prospec ts_july2013.pdf Accessed: March 11, 2018.

HydrogenEurope (2018): Hydrogen, enabling a zero emission Europe. https://www.hydrogeneurope.eu/sites/default/files/2018-

10/Public HE\%20Tech\%20Roadmaps full\%20pack 0.pdf Accessed: January $14,2020$.

IEA (2017): Global EV Outlook 2017. https://webstore.iea.org/global-ev-outlook2017 Accessed: January 14, 2020.

IEA (2019a): Tracking report. https://www.iea.org/reports/tracking-energyintegration/hydrogen Accessed: January 14, 2020.

IEA (2019b): Global EV Outlook 2019. https://webstore.iea.org/global-ev-outlook2019 Accessed: January 14, 2020.

KPMG (2017): Global Automative Executive Summary, 2017. https://assets.kpmg.com/content/dam/kpmg/xx/pdf/2017/01/globalautomotive-executive-survey-2017.pdf Accessed: February 03, 2018.

McKinsey (2012): Battery technology charges ahead.

https://www.mckinsey.com/business-functions/sustainability-and-resourceproductivity/our-insights/battery-technology-charges-ahead Accessed: February 03, 2018.

OICA (2016): World motor vehicle production. http://www.oica.net/wpcontent/uploads/World-Ranking-of-Manufacturers.pdf Accessed: February $01,2018$.

Portfolio (2017): Örült összehasonlitás: a Tesla Model 3 a 22 nagy riválisa ellen. https://www.portfolio.hu/vallalatok/cegauto/orult-osszehasonlitas-a-teslamodel-3-a-22-nagy-rivalisa-ellen.259233.html Accessed: February 03, 2018.

PwC (2014): Merre tart az elektromos autók piaca? https://www.pwc.com/hu/hu/kiadvanyok/assets/pdf/merre_tart_az_elektromos autok piaca-e-car 2014.pdf Accessed: February 03, 2018.

REW (2019): Ultra-fast EV chargers coming ultra soon as e-mobility manufacturers ramp up. https://www.renewableenergyworld.com/2019/04/05/ultrafast-evchargers-coming-ultra-soon-as-emobility-manufacturer-ramps-up/\#gref

Accessed: January 14, 2020.

Ross, S. A. (1976): The Arbitrage Theory of Capital Asset Pricing. Journal of Economic Theory, 13, 341-360.

Knudsen, C. - Doyle, A. (2018): Norway powers ahead (electrically): over half new car sales now electric or hybrid. https://www.reuters.com/article/usenvironment-norway-autos/norway-powers-ahead-over-half-new-car-salesnow-electric-or-hybrid-idUSKBN1ES0WC Accessed: February 03, 2018.

Supercharge.info (2020): https://supercharge.info/ Accessed: January 15, 2020.

Szandányi, L. (2016): Új időszámitás kezdödik az elektromos autózásban. https://www.portfolio.hu/vallalatok/uj-idoszamitas-kezdodik-az-elektromosautozasban.241411.html Accessed: February 03, 2018. 
Kollewe, J. (2015): Volkswagen emissions scandal - timeline.

https://www.theguardian.com/business/2015/dec/10/volkswagen-emissionsscandal-timeline-events Accessed: February 01, 2018.

Voelcker, J. (2017): Hybrid market share peaked in 2013, down since then. https://www.greencarreports.com/news/1108483_hybrid-market-sharepeaked-in-2013-down-since-then Accessed: February 03, 2018.

Yahoo Finance (2018): Share and market price datas. https://finance.yahoo.com/ Accessed: February 01, 2018.

\section{Appendix}

\section{Calculation of abnormal return}

The structure of the model is based on the study of Campbell-Lo-Mackinlay (1997).

Let $R_{t}$ be the $(N * 1)$ vector, which contains the returns of assets for $t$ period. Suppose that returns are independent distributions of normal probability variables with $\mu$ mean and $\Omega$ covariance matrix for each $t$ !

If the event was reported after the close of trading on the stock exchange:

- Let $\tau^{*}=\mathrm{T}_{1}$ be the time when the time occured, $\tau_{1}=\mathrm{T}_{1}+1$ and $\tau_{2}=\mathrm{T}_{2}$ the event window, and $\tau_{3}=\mathrm{T}_{0}+1$ and $\tau_{4}=\mathrm{T}_{1}$ the length of the estimation window.

On the other hand, if the event was reported during stock exchange trading:

- Let $\tau^{*}=0$ be the time when the time occured, $\tau_{1}=\mathrm{T}_{1}$ and $\tau_{2}=\mathrm{T}_{2}-1$ the event window, and $\tau_{3}=\mathrm{T}_{0}$ and $\tau_{4}=\mathrm{T}_{1}-1$ the length of the estimation window.

Figure 2 Schedule of the model when the event was reported after the close of trading on the stock exchange

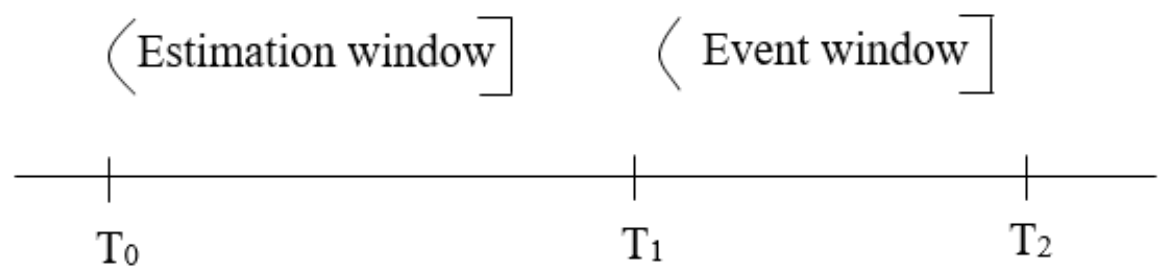

$\tau$

Source: own construction bases on Campbell et al. (1997)

Let there be a linear relationship between market and equity return:

$$
R_{i, t}^{*}=\alpha_{i}+\beta_{i} R_{m, t}
$$

where $R_{m, t}$ is the market return, $R_{i, t}^{*}$ is the vector containing the estimated returns on share, while $\alpha_{i}$ and $\beta_{i}$ are estimated from OLS regression based on the datas of the estimation window. The difference between the estimated return of a share 
$\left(R_{i, t}^{*}\right)$ and the actual realized return $\left(R_{i, t}\right)$ is the abnormal return, which is normally distributed:

$$
\begin{gathered}
\varepsilon_{i, t}=R_{i, t}-R_{i, t}^{*} \\
E\left[\varepsilon_{i, t}\right]=0 \quad \operatorname{Var}\left[\varepsilon_{i, t}\right]=\sigma_{\varepsilon_{i}}^{2}
\end{gathered}
$$

where $\sigma_{\varepsilon_{i}}^{2}$ is the estimated parameter of the model based on the datas of estimation window (lásd: Campbell et al. 1997, p. 158). Based on the estimated regression parameters $\left(\alpha_{i}, \beta_{i}\right)$, and the realized ex-ante market return, the abnormal yield can be calculated from Equation 3.2.. Based on the estimation period, the expected value of the abnormal return $(\mu=0)$ and the conditional variance matrix $\left(V_{i}\right)$ can be calculated (Campbell et al. 1997, p. 159). The one-day abnormal return thus has the distribution $\varepsilon_{i, t} \sim N\left(0, V_{i}\right)$ and the cumulative abnormal return follows the following distribution:

$$
\widehat{C A R}_{i}\left(\tau_{1}, \tau_{2}\right) \sim N\left(0, \sigma_{i}^{2}\left(\tau_{1}, \tau_{2}\right)\right)
$$

To standardize the cumulative abnormal return:

$$
\widehat{\operatorname{SCAR}}_{i}\left(\tau_{1}, \tau_{2}\right) \sim \frac{\widehat{C A R}_{i}\left(\tau_{1}, \tau_{2}\right)}{\sigma_{i}^{2}\left(\tau_{1}, \tau_{2}\right)}
$$

The result obtained follows Student's t-distribution with degree of freedom $\tau_{4}$ $\tau_{3}-1$ (Campbell et al. 1997, p. 161). The model assumes that a new event does not affect the share prices during the event window, so events are not clustered. 